\title{
Unique Presentation of Leukemic Cutaneous CD3/TCR- Phenotype T-Cell Lymphoma with Complete Remission after Allogeneic Stem Cell Transplantation
}

\author{
Lösemik Kutanöz T Hücreli Lenfomanın CD3/TCR- Fenotipi ile Nadir Prezentasyonu ve \\ Allojenik Kök Hücre Transplantasyonu ile Tam Remisyon
}

\author{
Hatice Şanlı ${ }^{1}$, Bengü Nisa Akay ${ }^{1}$, Seçil Saral ${ }^{1}$, Aylin Okçu Heper ${ }^{2}$, Pervin Topçuoğlu ${ }^{3}$ \\ ${ }^{1}$ Ankara University Faculty of Medicine, Department of Dermatology and Venereology, Ankara, Turkey \\ ${ }^{2}$ Ankara University Faculty of Medicine, Department of Pathology, Ankara, Turkey \\ ${ }^{3}$ Ankara University Faculty of Medicine, Department of Heamatology, Ankara, Turkey
}

To the Editor,

A 49-year-old male was admitted to our department with a 3-year history of pruritus and severe xerosis. Dermatological examination revealed squamation and ichthyosis with dark lamella involving the trunk and extremities (Figure 1). Physical examination revealed bilateral lower extremity edema.

Histopathological examination of the ichthyotic skin showed perivascular dermal lymphoid cell infiltration in the superficial dermis and nodular and dense lymphoid cellular infiltration in the deep dermis. Lymphoid cells were $\mathrm{CD} 3^{+}$and $\mathrm{CD} 20$ - with a loss of CD7 expression. There were numerous ( $>25 \%$ ) large, anaplastic cells with CD30 positivity among the lymphoid infiltrate. Clonal expansion of T cells in the lesional skin was demonstrated.

Complete blood count revealed $61.5 \times 10^{9} / \mathrm{L}$ (reference range: $4.5-$ 11) leukocytes with $15 \%$ Sezary cells. The axillary lymph node was consistent with N3 mycosis fungoides (MF) involvement. Thorax abdominal, and pelvic computed tomography was normal. Bone marrow biopsy revealed involvement with positive clonality.

Flow cytometric analysis of the peripheral blood revealed the CD3/ TCR complex in only 10\% of the T cells. The CD4/CD8 ratio was 23 among $T$ cells lacking $\mathrm{CD} 3$ expression and 1.6 among $\mathrm{CD}^{+}$cells.

The patient met the international criteria for Sezary syndrome [(SS); stage IVB, T4N3M1B2] and was diagnosed with ichthyosiform MF with large cell transformation with atypical flow cytometric phenotype $[1,2]$. According to the 2014 National Comprehensive Cancer Network Clinical Practice Guidelines [2], treatment was initiated as extracorporeal photopheresis, interferon-alpha-2a 3, and psoralen-UVA as first-line treatment without any response. The patient was unresponsive to polychemotherapy with gemcitabine and cisplatin and also three cycles of pralatrexate treatment. The patient underwent allogeneic hematopoietic peripheral stem cell transplantation (allo-HSCT) with an ablative conditioning regimen of cyclophosphamide $(120 \mathrm{mg} / \mathrm{kg})$ and total body irradiation (12 Gy) from an HLA-identical sibling donor. Cyclosporine A plus short-term methotrexate was given for graft-versus-host disease (GVHD) prophylaxis. Chronic sclerodermoid GVHD developed 1 year later and extracorporeal photopheresis was started for GVHD with complete response. After allo-HSCT, clonal T cells disappeared and skin lesions resolved completely.

There are only 5 patients showing negative TCR/CD3 complex in the literature and these patients were reported to have SS and atypical skin lesions, mainly non-erythrodermic leukemic variants, papuloerythroderma of Ofuji, prurigo nodularis, atopic dermatitis, papular xanthomatosis, and poikiloderma atrophicans vascularelike lesions $[3,4,5,6,7]$.

Allo-HSCT has been proven to be an effective therapy in MF/SS, demonstrating a decrease in the relapse rate and an overall increase in disease-free survival compared with conventional therapy. In a series of MF/SS transplants, Molina et al. [8] observed complete
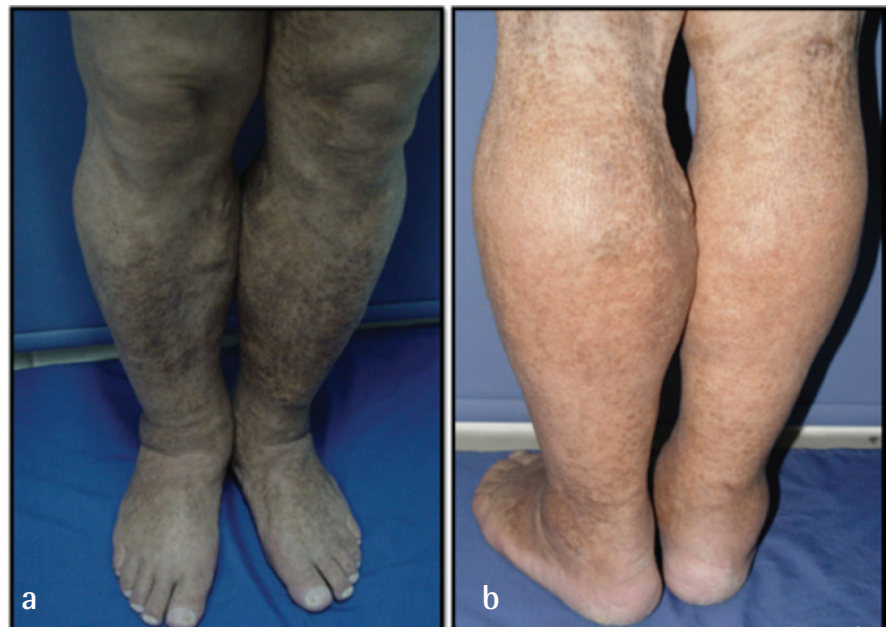

Figure 1. Ichthyotic plaques over anterior surface (a), and posterior surface (b) of lower extremities, edema and varicose dilatations of superficial veins are visible. 
remission of skin lesions in 100\% of patients after allo-HSCT. Duarte et al. [9] reported that 1 year after allo-HSCT, 42\% of their patients remained in remission. Use of total skin electron beam as a debulking agent before conditioning with non-myeloablative alloHSCT may reduce the severity of post-transplantation cutaneous GVHD [10].

In conclusion, our case is the first CD3-/TCR-SS patient presenting with generalized ichthyosis. All the patients with this immunophenotype are reported to have SS with intriguing skin lesions. These patients may require early initiation of more aggressive therapies. In our patient, allo-HSCT treatment resulted in cure and remission in a follow-up period of 3 years.

Keywords: Mycosis fungoides, Ichthyosiform, Sezary syndrome, Anaplastic, CD3/TCR-

Anahtar Sözcükler: Mikozis fungoides, İktiyotik, Sezary sendromu, Anaplastik, CD3/TCR-

Conflict of Interest: The authors of this paper have no conflicts of interest, including specific financial interests, relationships, and/ or affiliations relevant to the subject matter or materials included.

\section{References}

1. Wilcox RA. Cutaneous T-cell lymphoma: 2016 update on diagnosis, riskstratification, and management. Am J Hematol 2016;91:151-165.

2. https://www.ncen.org/professionals/physician_gls/pdf/nhl.pdf. accessed at 27/11/2016.
3. Shimauchi T, Sugita $K$, Nakamura M, Tokura Y. Leukaemic cutaneous T-cell lymphoma-manifesting papuloerythroderma with CD3(-) CD4(+) phenotype. Acta Derm Venereol 2010;90:68-72.

4. Lima M, Velho G, Alves R, Cunha M, Teixeira Mdos A, Canelhas A, Almeida J, Sachse F, Queiros ML, Santos AH, Fonseca S, Goncalves V, Massa A, Orfao A, Justica B. Atopic dermatitis-like non-erythrodermic leukemic variant of CD3(-/+dim) CD4(+) cutaneous T-cell lymphoma preceded by cutaneous papular xanthomatosis. Leuk Lymphoma 2004;45:597-603.

5. Taniguchi T, Sugaya M, Miyagaki T, Kogure A, Takekoshi T, Asano Y, Mitsui H, Sato S. Leukaemic variant of cutaneous T-cell lymphoma with CD3- CD4+ phenotype. Clin Exp Dermatol 2012;37:443-445.

6. Tokura Y, Yagi H, Seo N, Takagi T, Takigawa M. Nonerythrodermic, leukemic variant of cutaneous T-cell lymphoma with indolent clinical course: Th2type tumor cells lacking T-cell receptor/CD3 expression and coinfiltrating tumoricidal CD8 T cells. J Am Acad Dermatol 2000;43:946-954.

7. Fischer MB, Hauber I, Födinger M, Wolf HM, Thon V, Donath $\mathrm{P}$, Eibl MM, Knobler RM. Defective TCR surface expression associated with impaired TCR beta-chain assembly in a patient with cutaneous T-cell lymphoma. J Invest Dermatol 1995;104:537-540.

8. Molina A, Zain J, Arber DA, Angelopolou M, O'Donnell M, Murata-Collins J, Forman SJ, Nademanee A. Durable clinical, cytogenetic, and molecular remissions after allogeneic hematopoietic cell transplantation for refractory Sezary syndrome and mycosis fungoides. J Clin Oncol 2005;23:6163-6171.

9. Duarte RF, Canals C, Onida F, Gabriel IH, Arranz R, Arcese W, Ferrant A, Kobbe G, Narni F, Deliliers GL, Olavarria E, Schmitz N, Sureda A. Allogeneic hematopoietic cell transplantation for patients with mycosis fungoides and Sezary syndrome: a retrospective analysis of the Lymphoma Working Party of the European Group for Blood and Marrow Transplantation. J Clin Oncol 2010;28:4492-4499.

10. Duvic M, Donato M, Dabaja B, Richmond H, Singh L, Wei W, Acholonu S, Khouri I, Champlin R, Hosing C. Total skin electron beam and non-myeloablative allogeneic hematopoietic stem-cell transplantation in advanced mycosis fungoides and Sezary syndrome. J Clin Oncol 2010;28:2365-2372.
Address for Correspondence/Yazışma Adresi: Seçil SARAL, M.D., Ankara University Faculty of Medicine, Department of Dermatology and Venereology, Ankara, Turkey Phone : +90 5054324682

E-mail : secilsaral@gmail.com
Received/Geliş tarihi: October 03, 2016

Accepted/Kabul tarihi: December 21, 2016

DOI: 10.4274/tjh.2016.0395 